\title{
Sejarah Dan Arkeologi Madura Barat Abad XIV-XVIII: Sebuah Pengenalan Tentang Penguasanya
}

\section{Lucas Partanda Koestoro}

Keywords: heritage, Madura, artifact, ethnography, history, culture

\section{How to Cite:}

Koestoro, L. P. Sejarah Dan Arkeologi Madura Barat Abad XIV-XVIII: Sebuah Pengenalan Tentang Penguasanya. Berkala Arkeologi, 15(2), 45-61. https://doi.org/10.30883/jba.v15i2.660

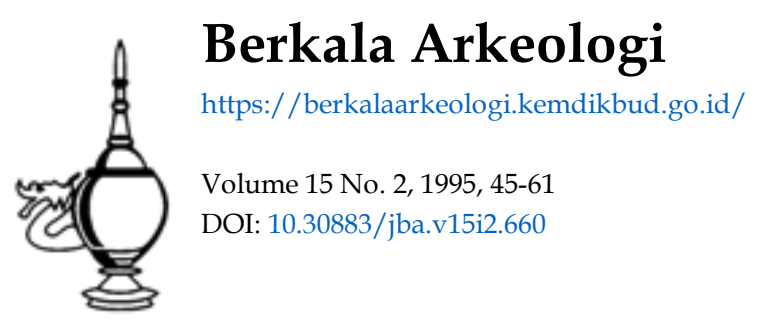

\section{(c) (1) (9)(2)}

This work is licensed under a Creative Commons Attribution-NonCommercial-ShareAlike 4.0 International License. 


\title{
SEJARAH DAN ARKEOLOGI MADURA BARAT ABAD XIV-XVIII: Sebuah Pengenalan Tentang Penguasanya
}

\author{
Lucas Partanda Koestoro \\ (Balai Arkeologi Yogyakarta)
}

\section{Pengantar}

Selat Madura yang memisahkan Pulau Jawa dan Pulau Madura sejak dulu digunakan sebagai lalu lintas pelayaran yang menghubungkan bagian barat dan bagian timur Nusantara. Berdasarkan hal itu, maka Selat Madura berfungsi sebagai jalur simpang dari jalur pokok pelayaran tradisional yang membentang dari Laut Jawa ke timur. Dengan demikian, Selat Madura tidak hanya berperan sebagai jalur perdagangan laut melainkan digunakan pula sebagai jalur perluasan kekuasaan politik, penyebaran agama, dan kebudayaan.

Peninggalan kepurbakalaan di Pulau Madura bagian barat, merupakan hasil budaya pada masanya. Peninggalan-peninggalan itu sebagian besar berupa makam dan yang lainnya --yang sekarang hanya tersisa namanya saja.- lebih dikenal sebagai bekas lokasi pusat pemerintahan yang berupa kraton. Di antara makam-makam itu yang terkenal antara lain Makam Aermata Ibu, Pasarean Makam Agung, Makam Agung Blega, dan Makam Sultan. Sementara itu, nama tempat yang dikaitkan dengan pusat-pusat kekuasaan Madura Barat "tempo dulu" adalah Madegan, Palakaran, Tonjung, Sembilangan, dan Bangkalan.

Satu aspek menarik yang berkaitan dengan peninggalan kepurbakalaan di Pulau Madura adalah hubungan tokoh-tokoh di belakangnya dengan perjalanan sejarah yang mewarnainya. Dengan cara mengatur pandangan atas keberadaan berbagai "peninggalan" masa lalu di Madura Barat itu, diharapkan muncul rangsangan untuk lebih mengenali berbagai hal yang dikandungnya. yaitu hubungan antara Madura dan Jawa.

\section{Penguasa Madura Barat dan silsilahnya.}

Ditilik dari segi politik, hubungan antara Madura dan Jawa telah terjalin lama. Pararaton misalnya, antara lain menceritakan tentang pemindahan Wiraraja oleh kekuasaan Singasari ke Sumenep, di ujung timur Pulau Madura. Begitu pula kisah tentang pengungsian Raden Wijaya, yang kelak mendirikan kerajaan Majapahit, ke Pulau Madura 
setelah kerajaan Singasari runtuh dan raja Krtanagara mati terbunuh, yaitu yang tertulis dalam kisah pembukaan hutan Trik di Jawa Timur oleh orang-orang Madura di bawah pimpinan Raden Wijaya (Padmapuspita, 1966).

Bila pada awalnya penduduk Pulau Madura -khususnya bagian timur- ikut membantu merintis pendirian kerajaan Majapahit, belakangan terlihat adanya peran kerajaan Majapahit dalam pembentukan kerajaan di Pulau Madura -khususnya bagian barat. Di akhir abad ke13. Pulau Madura serta daerah lain di Jawa Timur yang sebelumnya merupakan wilayah kekuasaan kerajaan Singasari, sudah dapat dianggap sebagai wilayah kerajaan Majapahit. Bahkan pada awal abad ke-14, seperti yang diberitakan dalam Nagarakretagama dan Pararaton, wilayah kekuasaan kerajaan Majapahit telah meliputi seluruh daerah Jawa Timur dan juga Pulau Madura (Slametmulyana, 1979).

Mengacu pada sumber tertulis seperti Babad Tanah Jawa dan Babad Songennep maupun ceritera rakyat Pulau Madura, diperoleh beberapa hal yang berhubungan dengan tokoh serta lembaga kekuasaan yang timbul di Pulau Madura, khususnya Madura Barat yang menjadi pokok pembicaraan dalam tulisan ini. Menarik untuk diperhatikan bahwa tokoh-tokohnya dikatakan sebagai keturunan raja Majapahit (Kartodirdjo,1973). Secara garis besar, gambaran tentang tokoh dan lembaga kekuasaanya adalah seperti tertera di bawah ini

Masyarakat percaya bahwa silsilah penguasa Madura Barat berawal dari dua orang keturunan Brawijaya ${ }^{1}$ yang terakhir, yakni Aria Lembu Peteng dan Aria Menak Sanaya Aria Lembu Peteng, dikenal sebagai anak Brawijaya melalui perkawinannya dengan Puteri Campa, menjadi penguasa di Madegan², Sampang. Adapun Aria Menak Sanaya yang menjadi penguasa di Proppo ${ }^{3}$, Pamekasan, adalah anak

1 Secara umum diketahui bahwa Brawijaya adalah nama tradisional untuk menyebut semua raja Majapahit (Wibowo, 1983).

2 Hingga kini tidak banyak informasi tentang adanya peninggalan budaya yang berkaitan langsung dengan keberadaan kraton di masa lalu di sana. Kita hanya mengenal adanya Makam Madegan, yang secara administratif berada di wilayah Kelurahan Polagan, Kecamatan Sampang. Kabupaten Sampang. tempat dimakamkannya Ratu Ibu dan keluarga Cakraningrat

3 Proppo yang berada sekitar $12 \mathrm{~km}$ di sebelah barat kota Pamekasan diketahui mengandung sisa dua buah "candi" yang seluruhnya terbuat dari bata. Sayang sekali kondisinya sangat parah karena bata-bata pembentuknya telah 
Aria Damar. Aria Damar penguasa Palembang adalah saudara seayah Aria Lembu Peteng. Di kemudian hari, seorang cucu Aria Menak Sanaya yang bernama Aria Pocok kawin dengan Nyai Ageng Budo, cicit Aria Lembu Peteng. Aria Pocok kemudian menjadi penguasa di Madegan, menggantikan kedudukan mertuanya. Perkawinan kedua keturunan raja Majapahit itu melahirkan Kyai Demung (Kamar,1926, Graaf \& Pigeaud, 1974).

Setelah Kyai Demung menggantikan ayahnya sebagai penguasa Madegan, ia memindahkan pusat kekuasaan ke Palakaran ${ }^{4}$ Selanjutnya Kyai Demung digantikan anaknya yang bernama Kyai Pragalbo, yang kemudian dikenal pula sebagai Pangeran Palakaran.

Pada tahun 1531 Pangeran Pratanu naik tahta menggantikan Kyai Pragalbo (Kartodirdjo, 1973). Kejadian itu diikuti dengan tindakannya memindahkan pusat kekuasaan dari Palakaran ke Arosbaya ${ }^{5}$, di sebelah utara Palakaran. Gelar yang dipakainya adalah Panembahan Lemah Duwur. Sebuah sumber menyebutkan bahwa kejadian tersebut berlangsung pada tahun 1450 AJ (Kamar, 1926). Pada masa pemerintahannya, Pangeran Pratanu memperluas kekuasaan atas Blega dan Sampang (Graaf \& Pigeaud,1974). Bahkan Pamekasan dan Sumenep berada di bawah pengaruhnya. Beliau

dibongkar dan dimanfaatkan untuk berbagai kepentingan (Vorderman, 1893) Belum dapat diketahui apakah "tumpukan bata" itu merupakan sisa dari bangunan suci keagamaan yang mandiri, atau bagian sebuah permukiman penguasa masa lalu ("kraton").

- Palakaran yang dikenal sekarang adalah nama desa di wilayah Kecamatan Arosbaya, kurang-lebih $15 \mathrm{~km}$ di sebelah timurlaut kota Bangkalan. Beberapa ratus meter di sebelah selatan Desa Palakaran terdapat sebuah kompleks pemakaman. Di Pasarean Makam Agung yang berada di wilayah Desa Makam Agung itu dimakamkan Pangeran Pragalbo dan Pangeran Pratanu. petinggi Madura yang belakangan dianggap memiliki peran tersendiri dalam proses sosialisasi islam di Madura (Barat).

5 Arosbaya yang terletak sekitar $15 \mathrm{~km}$ di timurlaut Bangkalan merupakan kota kecamatan yang berada di pantai Laut Jawa (pesisir utara Pulau Madura) Muara sungainya merupakan lokasi awal permukman wilayah ini. Dahulu Arośbaya merupakan bandar yang berperan dalam perdagangan laut, namun tidak berkembang menjadi bandar besar. Bersama-sama dengan Bangkalan. Kwanyar, Blega, dan Sampang. urusan kesyahbandaran. Arosbaya dikuasi oleh Kompeni pada tahun 1746 (Tjiptoatmodjo,1983). Hal ini menunjukkan bahwa pada saat itu Arosbaya masih berperan sebagai bandar dalam perdagangan laut, dan mampu memberi keuntungan melalui pajak-pajak yang harus dibayar oleh pengguna jasanya 
memerintah cukup lama, sampai tahun 1512 AJ (Kamar, 1926) atau tahun 1592 dan digantikan oleh anaknya yang bernama Pangeran Tengah (Kartodirdjo, 1973), hasil perkawinannya dengan triman dari raja Pajang (Graaf \& Pigeaud, 1974).

Ketika Pangeran Tengah meninggal pada tahun 1620 (Graaf \& Pigeaud, 1974), atau 1621, pemerintahan selanjutnya dipegang oleh saudara laki-lakinya yang bernama Pangeran Mas --anak Panembahan Lemah Duwur dengan Ratu Ibu dari Madegan, Sampang (Kamar, 1926)-- karena putera mahkota yang bernama Raden Prasena masih kecil (Kartodirdjo,1973). Oleh ibunya, Raden Prasena dibawa ke Sampang dan diserahkan kepada pamannya yang bernama Pangeran Sontomerto, yang ketika menjadi penguasa di Madegan. Sumber loka. menyebutkan bahwa hal itu berlangsung pada tahun 1542 AJ (Kamar, 1926)

Peristiwa besar yang dialami pada masa pemerintahan Pangeran Mas adalah serangan pasukan Jawa atas Pulau Madura. Pada tahun 1624, setelah melakukan serangan sebanyak dua kali, kerajaan Mataram yang pada waktu itu di bawah pemerintahan Sultan Agung berhasil menaklukkan kerajaan Madura Barat. Diperkirakan pasukan Mataram menyerang Pulau Madura melalui daerah Pasuruan yang pada tahun 1617 telah diduduki pasukan Mataram (Graaf \& Pigeaud, 1974). Pertempuran hebat antara pasukan Madura Barat yang dibantu pasukan Sumenep dan Pamekasan melawan pasukan Mataram, terjadi di dekat Sampang. Mengerti akan kekalahan pasukannya, Pangeran Mas melarikan diri ke Giri dan meninggal di sana. Raden Prasena dibawa ke Mataram (Graaf \& Pigeaud, 1974).

Di Mataram, Raden Prasena mendapat perlakuan yang baik bahkan kemudian diberi wewenang untuk memerintah di Pulau Madura. Sultan Agung memberinya gelar Pangeran Cakraningrat I dan dikawinkan dengan seorang puteri kraton Mataram yang bernama Ratu $\mathrm{Ibu}^{6}$ (Kartodirdjo, 1973).

6 Versi lain menyatakan bahwa Ratu lou adalah puteri dan Susuhunan Giri (Graaf, 1962). Dalam kaitannya dengan tokoh ini. kita mengenal situs Makam Aermata lbu yang berada di wilayah Desa Buduran. Kecamatan Arosbaya, sekitar $3 \mathrm{~km}$ di sebelah timur ibukota kecamatan Arosbaya.

Selain Ratu lbu, tokoh-tokoh penguasa Madura Barat yang dimakamkan di sana adalah Pangeran Cakraningrat II (1570-1630), Pangeran Cakraningrat IV (1640-1669), Panembahan Cakraningrat V (1669-1695). Panembahan Cakraningrat VI (1695-1705) dan Sultan Cakraadiningrat I (1705-1742) 
Pemerintahan Madura Barat di bawah Pangeran Cakraningrat berpusat di Sampang. Dalam prakteknya, Pangeran Cakraningrat lebih banyak tinggal di Mataram. Hal ini berkenaan dengan perintah yang sering diterimanya untuk memimpin pasukan menyerang daerahdaerah yang membangkang terhadap kekuasaan Mataram (Kamar. 1926)

Ketika pengganti Sultan Agung yang bernama Sunan Amangkurat I memerintah, pada tahun 1647 di Mataram terjadi pemberontakan yang dipimpin oleh Pangeran Alit Pangeran Alit adalah adik Sunan Amangkurat I. Pangeran Cakraningrat I yang mendapat perintah untuk memadamkan pemberontakan itu gugur dan dimakamkan di Imogiri, sehingga sering pula disebut Pangeran Sedeng Magiri. Putera tertuanya yang bernama Raden Dermang Melayakusuma juga gugur dalam tugas yang sama. Pengganti Pangeran Cakraningrat I adalah adik Raden Demang Melayakusuma yang bernama Raden Undagan. Penguasa Madura Barat yang baru, pilihan Sunan Amangkurat I itu memakai gelar Pangeran Cakraningrat II (Kartodirdjo, 1973).

Sebagaimana Pangeran Cakraningrat I, Pangeran Cakraningrat II juga banyak menghabiskan waktunya di ibukota Mataram. Kenyataan ini, ditambah dengan anggapan bahwa pilihan Sunan Amangkurat 1 tidak tepat dalam menentukan pewaris tahta kekuasaan Madura Barat, menyebabkan Trunajaya, kemenakan Pangeran Cakraningrat II melakukan pemberontakan (Graaf,1940). Anak Raden Demang Melayakusuma itu berhasil merebut kekuasaan atas Madura Barat dan menangkap Pangeran Cakraningrat II yang kemudian dibuang ke Lodaya, Jawa Timur. Selanjutnya Trunajaya membawa pasukannya menyeberangi Selat Madura menyerang pusat pemerintahan Mataram (Kamar, 1926).

Berkat bantuan Kompeni, Sunan Amangkurat II yang menggantikan ayahnya sebagai penguasa Mataram berhasil memadamkan pemberontakan Trunajaya. Pangeran Cakraningrat II kembali menduduki tahta kekuasaan atas Madura Barat Pusat

Satuan objek arkeologi yang istimewa dari situs ini adalah ghunongan, tabir di bagian belakang kubur yang dipenuhi dengan ukiran halus. Objek sejenis juga dijumpai di situs Kolpajung Laok, Pamekasan. Adapun tokoh utama yang dimakamkan di sana adalah Panembahan Ronggosukowatı (yang meninggal sekitar tahun 1600) dan Pangeran Jimat (Kempers. 1959 
pemerintahan dipindahkannya ke kota baru yang dinamakan Tonjung ${ }^{7}$ (Kamar, 1926)

Setelah kematian Pangeran Cakraningrat II karena sakit di Kamal, putera tertuanya diangkat sebagai penggantinya dengan nama Pangeran Cakraningrat III. Pada masa pemerintahannya terjadi pemberontakan yang diawali dengan perselisihan keluarga. Penguasa Pamekasan yang bernama RA Adikara, menantu Pangeran Cakraningrat III, memimpin pasukannya menyerang Tonjung. RT Suroadiningrat, adik Pangeran Cakraningrat III ditugaskan untuk memadamkan pemberontakan tersebut. Ternyata RT Suroadiningrat berbalik menyerang Pangeran Cakraningrat III. Pangeran Cakraningrat III dan keluarganya lari ke sebuah kapal perang Kompeni di salah satu pelabuhan Madura Barat, tetapi kematian di tangan pelaut kapal perang itu yang dijumpainya. Hal itu melahirkan sebuah nama lain baginya, yakni Pangeran Sedeng Kapal yang artinya pangeran yang meninggal di kapal. Penggantinya sebagai penguasa Madura Barat adalah RT Suroadiningrat (Kamar, 1926).

Oleh Sunan Pakubuwono I, RT Suroadiningrat sebagai penguasa Madura Barat diberi gelar Pangeran Cakraningrat IV. la memindahkan ibukota Madura Barat dari Tonjung ke Sembilangan". Alasannya

7 Sejak dlpullhkannya Pangeran Cakraningrat II sebagai penguasa Madura Barat, pusat kedudukan pemerintahan pindah dari Sampang ke Tonjung yang berada di sebelah baratnya. Tonjung terletak sekitar $5 \mathrm{~km}$ di sebelah tenggara Bangkalan.

8 Sembilangan terletak di tepi pantal, $10 \mathrm{~km}$ di sebelah baratdaya Bangkalan. Ruas selat di Sembilangan adalah bagian paling sempit dari Selat Madura. Jarak dari pantai Sembilangan di daratan Pulau Madura dengan daratan Sedayu di Greslk hanya 2,5 km. Penguasaan atas wilayah ini memungkinkan pengawasan atas arus lalu lintas pelayaran pada jalur yang ramai itu. maupun pengawasan dalam kaitannya dengan pengamanan wilayah karena seringnya terjadi peperangan.

Bersamaan dengan Itu, dibangun pula sebuah "kraton" kecil di Tanjung Anyar (biasa dlsebut Junganyar) dengan maksud yang sama, darimana dapat diamankan pantai di bagian lebih selatan. Saat ini sisa yang masih dapat dilihat adalah sebuah gapura, penduduk menamakannya labang mesem, yang terbuat dari bata. Patut dikemukakan bahwo pembangunan struktur bata itu menerapkan teknik kosod, artinya bata-bata itu saling digosokkan satu sama lain sambil diberi sedikit air untuk merekatkannya. Jadi tidak menggunakan spesi/adukan (Hoom, 1889). 
karena Tonjung telah dirusak oleh pasukan Bali yang sebetulnya diminta datang oleh Pangeran Cakraningrat III untuk membantu memadamkan pemberontakan yang dipimpin oleh RA Adikara.

Tentangannya terhadap kekuasaan Kompeni menyebabkan Madura Barat diserang dan ibukotanya, Sembilangan, diduduki Kompeni. Pangeran Cakraningrat IV melarikan diri ke Banjarmasin tetapi tertangkap dan dibawa ke Batavia untuk selanjutnya dibuang ke Kaap, Tanjung Harapan (Kamar, 1926).

Putera Pangeran Cakraningrat IV dari perkawinannya dengan Ratu Ayunan yang menjabat bupati Sedayu, diangkat oleh Kompeni sebagai penguasa Madura Barat Ratu Ayunan adalah saudara sedarah Sunan Pakubuwono III. Nama yang diberikan kepada penguasa Madura Barat baru itu adalah RA Secoadiningrat I dan belakangan diberi gelar Panembahan Adipati Cakraningrat $V$ (Kamar, 1926).

Pada tahun 1695 AJ (= 1769 AD), cucunya menggantikan Panembahan Adipati Cakraningrat V sebagai penguasa Madura Barat la bergelar Panembahan Adipati Cakraningrat VI dan meninggal pada tahun 1705 AJ (= 1779 AD). Penggantinya adalah pamannya sendiri yang kelak bergelar Pangeran Adipati Cakraningrat VII (Kamar 1926).

\section{Situasi politik dan pergolakan yang ditimbulkan}

Seperti telah disebutkan sebelumnya dalam Nagarakretagama dan Pararaton, awal abad ke-14 Pulau Madura sudah merupakan bagian dari kerajaan Majapahit. Oleh sebab itu bukan hal yang aneh bila keturunan raja Majapahit menjadi penguasa di Madura Barat. Hal ini dapat dikaitkan dengan upaya mendapatkan kepastian akan adanya loyalitas yang tinggi dari daerah Madura Barat khususnya dan Pulau Madura umumnya terhadap kekuasaan induk Majapahit

Mungkin juga terjadi bahwa pengakuan sebagai keturunan raja Majapahit digunakan untuk mengabsahkan kedudukan penguasa di depan rakyat Madura. Seperti yang sudah umum diketahui dalam pemerintahan yang bersifat kerajaan, silsilah merupakan sesuatu yang sangat dipentingkan. Selain itu, dalam masyarakat kuna. silsilah

Dipindahkannya pusat pemerintahan oleh Pangeran Cakraningrat IV ke Sembilangan, disebabkan karena Tonjung telah rusak akibat serangan pasukan Bali yang sebetulnya dimintai tolong oleh Pangeran Cakraningrat III 

(Darmosoetopo, 1980).

Bukti yang ditemukan selama ini menyatakan adanya pengaruh Hindu-Buda di Pulau Madura. Di beberapa lokasi, seperti di wilayah Kabupaten Pamekasan dan Sumenep, pada akhir abad ke-19 masih dapat dikenali adanya sisa candi serta penemuan arca-arca Buda, yaitu Aksobhya dan Ratnasambhawa dan arca Hindu, Siwa Mahadewa dan tokoh dewi (Vorderman, 1893). Ini dapat dimengerti mengingat dominasi politik Majapahit cukup lama atas Pulau Madura --bahkan jauh sebelumnya-- hingga awal kedatangan pengaruh Islam di tanah tersebut Terlebih lagi bila diingat bahwa Pulau Madura terletak sangat dekat dengan daratan Jawa, sehingga penduduknya mempunyai mobilitas yang tinggi Kondisi tanah Pulau Madura yang kurang subur menjadikan mobilitas tinggi itu sebagai syarat mutlak dalam pemenuhan kebutuhan hidup melalui jalur perdagangan.

Dampak keruntuhan Majapahit yang terjadi pada tahun 1519 cepat terlihat di Pulau Madura. Selain disebabkan oleh adanya pertentangan dan perpecahan dalam keluarga raja dengan memperebutkan kekuasaan atas tahta, keruntuhan itu dipercepat oleh munculnya kekuatan politik baru di pesisir utara Jawa, yakni Demak (Djafar,1978). Perbedaan landasan keagamaan antara Demak dan Majapahit itulah yang antara lain memungkinkan terjadinya penaklukan Majapahit oleh Demak (Djafar, 1978).

Dalam konteks ini, dapat disebutkan bahwa sosialisasi Islam di Madura Barat telah berlangsung sejak masa pemerintahan Lembu Peteng, yang diangkat oleh Raja Majapahit berkedudukan di Madegan, Sampang. Ketika terjadi pertentangan antara Majapahit dan kekuatankekuatan pesisir utara Jawa, ia memihak penganut Islam. Pada masa Majapahit runtuh (1486 menurut Kronik Madura), Lembu Peteng berkuasa di Pamekasan (Hageman, 1857)

Sementara itu orang pertama di kalangan kaum bangsawan Madura yang kemudian memeluk agama Islam adalah Pangeran Pratanu pada tahun 1450 AJ atau 1528 (Graaf \& Pigeaud,1974). Diceritakan bahwa atas permintaan putra mahkota yang bernama Pangeran Pratanu, Kyai Pragalbo memerintahkan Empu Bageno, seorang patih kerajaan, untuk belajar agama Islam ke Kudus. Setelah Empu Bageno sendiri diislamkan oleh Sunan Kudus, ia kembali ke Palakaran sebagai seorang muballigh. Pangeran Pratanu mengikuti jejak Empu Bagendo menjadi penganut Islam. Pada akhir hayatnya Kyai Pragalbo juga memeluk agama Islam, dan dikenal dengan sebutan Pangeran Islam Ongghu karena sebelum meninggal beliau 
mengangguk ketika diminta untuk memeluk agama Islam oleh Pangeran Pratanu (Kamar, 1926).

Kita juga dapat menganggap bahwa sikap Pangeran Pratanu itu merupakan titik awal pengakuan Madura Barat atas kekuasaan Demak sebagai pengganti Majapahit (Graaf \& Pigeaud,1974). Di luar hal-hal khusus, dimungkinkan pula bahwa sikap itu dilandasi oleh keinginannya untuk menghindari serangan Demak, seperti yang terjadi terhadap beberapa kerajaan vasal Majapahit yang tidak atau belum memeluk agama Islam. Bahkan Pangeran Pratanu juga ikut mengirimkan pasukan dalam usaha Demak menaklukkan beberapa kerajaan vasal itu (Graaf \& Pigeaud,1974). Melalui cara pandang tertentu, memang dapat dilihat bahwa kekuasaan politik cukup banyak membantu dalam usaha sosialisasi Islam.

Pada masa pemerintahannya yang mengakui superioritas Demak, Panembahan Lemah Duwur sibuk memperkukuh dan memperluas wilayah kekuasaan. Usahanya yang berhasil mempersatukan Pulau Madura di bawah pengaruh kekuasaannya mungkin bukan hanya disebabkan oleh sifat ekspansionis kerajaan yang diperintahnya, namun juga dalam rangka mengemban tugas dari Demak sebagai bukti keloyalannya.

Setelah Demak tidak lagi memegang dominasi politik karena munculnya Pajang. Panembahan Lemah Duwur kawin dengan seorang puteri kraton Pajang. Perkawinan ini merupakan dasar ikatan yang pertama kali antara kerajaan Madura Barat dengan kekuasaan di Jawa Tengah. Sejak itu, mungkin ada semacam rasa segan pada penguasa pengganti Sultan Pajang terhadap penguasa Madura Barat Hal itu terlihat ketika pengganti Panembahan Lemah Duwur yang bernama Pangeran Tengah sedang berkuasa. Raja pertama Mataram di Jawa Tengah tampaknya tidak mengadakan usaha agar Madura Barat mengakui kekuasaannya (Graaf \& Pigeaud,1974). Kemudian, pada masa pemerintahan Sultan Agung, penguasa Madura Barat menggabungkan diri dengan raja-raja Jawa Timur untuk menahan serangan pasukan Mataram di dekat Japan, daerah Mojokerto sekarang (Graat \& Pigeaud, 1974).

Pada awal pemerintahannya, Pangeran Tengah harus berperang melawan Blega dan Sampang. Ketika itu Blega berada di bawah pemerintahan adiknya yang bernama Sakatah (Graaf \& Pigeaud, 1974), yang dikenal pula sebagai Raden Koro atau Pangeran Blega, anak Panembahan Lemah Duwur dengan Ratu Ibu yang berasal dari Madegan, Sampang (Kamar, 1926). Usaha Blega untuk melepaskan diri dari pengaruh kekuatan Arosbaya tidak berhasıl 
Kejadian besar yang berlangsung pada masa pemerintahan Pangeran Mas pengganti Pangeran Tengah adalah serangan pasukan Mataram yang waktu itu di bawah pemerintahan Sultan Agung. Ketika akhirnya Mataram berhasil mengalahkan Madura Barat pada tahun 1624, beberapa kota seperti Bangkalan, Arosbaya, Blega, dan Sampang didudukinya (Tjiptoatmodjo,1983). Pangeran Mas melarikan diri ke Gresik, sedangkan Pangeran Blega yang juga ikut mengerahkan pasukannya melawan Mataram ditangkap dan kemudian dibunuh (Kamar, 1926).

Akibat peristiwa itu, Prasena, putera Pangeran Tengah yang sebetulnya putera mahkota Madura Barat, dibawa ke Mataram dan dikawinkan dengan seorang puteri kraton Mataram. Agak berbeda dengan perkawinan Panembahan Lemah Duwur, perkawinan Prasena dengan puteri kraton Mataram justru merupakan ikatan yang berakibat bahwa Madura Barat menjadi kerajaan vasal dari Mataram di Jawa Tengah. Untuk memudahkan pengawasan atas Madura Barat, Prasena yang kelak bergelar Pangeran Cakraningrat I diharuskan untuk lebih banyak berdiam di Mataram.

Cara tersebut di atas, bagi Mataram memang merupakan hal yang lazim dilakukan. Letak pusat pemerintahan kerajaan induk dengan kerajaan vasal yang saling berjuang tidak memungkinkan dilakukan pengawasan secara ketat Hal tersebut disebabkan oleh kurangnya sarana komunikasi yang sempurna pada waktu itu. Dikuatirkan bila penguasa kerajaan vasal tidak dapat diawasi secara ketat, dapat menimbulkan kesulitan bagi kerajaan induk.

Cara seperti itu memungkinkan Mataram -pada masa pemerintahan Sultan Agung- mencapai puncak kejayaannya. Wilayah kekuasaannya ketika itu meliputi Jawa Tengah, Jawa Timur berikut pulau Madura, dan sebagian Jawa Barat (Sutjipto, 1977).

Pada masa pemerintahan raja-raja pengganti Sultan Agung. tampak ada kemunduran wilayah kekuasaan, sebagai akibat adanya pertentangan di kalangan pejabat dalam struktur birokrasi kerajaan memberi kesempatan kepada Kompeni untuk melakukan intervensi. Sebagai akibat intervensi itu, dapat diketahui Mataram harus membayar mahal dengan penyempitan wilayah kekuasaan (Sutjipto, 1977).

Bila pada masa pemerintahan Sultan Agung dengan kekuatan militernya mampu menekan dan menundukkan penguasa-penguasa daerah Jawa Timur, namun sejak munculnya perlawanan Surapati (1686-1703) dan seterusnya yang terjadi pada masa pemerintahan Amangkurat II, III, Pakubuwono I, dan Amangkurat IV --yang meliputi masa antara tahun 1686-1727--, kekuasaan Mataram di daerah pantai 
Selat Madura merosot bahkan menjelang pertengahan abad ke-18 mengalami desintegrasi (Tjiptoatmodjo, 1983)

Kembali ke Madura Barat, ketika Pangeran Cakraningrat I memerintah, timbul pemberontakan yang dipimpin oleh Trunajaya yang masih kemenakannya sendiri. Pemberontakan Trunajaya dapat dianggap sebagai pemicu perpecahan di Mataram Ketika pemberontakan Trunajaya berlangsung. Sunan Amangkurat II terpaksa mengungsi karena kratonnya di Plered dihancurkan oleh Trunajaya Pengungsian itu memberi kesempatan kepada Pangeran Puger untuk mengangkat dirinya sebagai Sunan Pakubuwono I Kenyataannya Sunan Amangkurat II pernah menjadi sekutu Trunajaya ketika melawan ayahnya sendiri yakni Sunan Amangkurat I atas dorongan Trunajaya Kejadian ini memberi jalan bagi Kompeni ke arah perluasan wilayah dalam rangka penjajahan (Kartodirdjo, 1973).

Sementara itu Mataram, usaha Pangeran Puger untuk menjadi raja dengan gelar Sunan Pakubuwono I diawali dengan adanya peperangan dengan Sunan Amangkurat II. Dalam pandangan Pangeran Puger, Pangeran Cakraningrat II berjasa besar terhadapnya Sampai saat meninggalnya pada tahun 1707, Panembahan Cakraningrat II banyak membantu Kompeni. Di antaranya adalah pengiriman pasukan Madura untuk melaksanakan penangkapan dan penghancuran Untung Suropati pada tahun 1686 di daerah Kartasura (Kartodirdjo, 1973).

Bertolakbelakang dengan Panembahan Cakraningrat II yang bersekutu dengan Kompeni, Pangeran Cakraningrat IV justru menentang Kompeni. Seperti yang pernah dilakukan oleh Trunajaya, Pangeran Cakraningrat IV mengadakan ekskpansi wilayah kekuasaan la menaklukkan Sumenep dan menyeberangi Selat Madura menyerang Surabaya dan Probolinggo. Selain itu, ia sempat pula menduduki pusat kerajaan Mataram di Kartasura. Akibat politik ekspansinya itu, maka ketika Pangeran Cakraningrat IV menduduki Sumenep, penguasa yang dikalahkan meminta bantuan kepada Kompeni. Pasukan Madura Barat dapat dikalahkan dan akhirnya Pangeran Cakraningrat IV melarikan diri ke Banjarmasin. Oleh penguasa di sana ia diserahkan ke Batavia untuk seterusnya dibuang oleh Kompeni ke Kaap, Tanjung Harapan (Kamar 1926) sebagai akibat dari perlawanan itu, kota-kota di Madura Barat. yakni Sampang, Blega, Kwanyar, dan Sembilangan diserang Kompeni (Tjiptoatmodjo, 1983).

Sebagai pengganti ayahnya, Kompeni mengangkat putera Pangeran Cakraningrat IV, menjadi penguasa Madura Barat Gelar yang digunakan adalah Pangeran Adipati Secoadiningrat I la 
mendirikan kota Bangkalan pada tahun 1681 AJ (=1755 AD) dan dari sana menjalankan pemerintahannya yang tidak lagi diwarnai kerusuhan. Belakangan ia memperoleh gelar baru dari Kompeni di Batavia, ialah Pangeran Adipati Cakraningrat V (Kamar, 1926)

Sejak masa pemerintahannyalah kota Bangkalan dijadikan tempat kedudukan penguasa-penguasa Madura Barat. Sebelum itu, pusat kekuasaan Madura Barat berpindah-pindah dari Sampang, Palakaran, Tonjung, dan Sembilangan (Hoorn, 1889).

Berhubungan dengan adanya pengawasan yang cukup ketat oleh Kompeni atas daerah jajahannya, seperti halnya pada masa pemerintahan Panembahan Adipati Cakraningrat $V$, pemerintahan Panembahan Adipati Cakraningrat VI juga berjalan tenang. Tidak ada kerusuhan seperti yang dialami oleh penguasa-penguasa Madura Barat sebelumnya.

\section{Penutup}

Berbagai pergolakan yang mewarnai kehidupan masyarakat dan institusi kekuasaan di Madura Barat merupakan setting dari kemunculan berbagai hasil budaya masa lalu, yang sebagian di antaranya berupa objek arkeologi serta toponim. Masuk dalam pengertian toponim di sini adalah nama tempat yang berdasarkan keterangan turun-temurun merupakan bekas lokasi pusat institusi kekuasaan pada masanya Bila untuk objek arkeologinya, dapat dilihat dengan jelas berbagai sisa hasił budaya pada masanya, maka di lokasi-lokasi yang disebut sebagai bekas berdirinya kraton amat minim. Untuk hal yang terakhir ini kita boleh menerimanya dengan mengakui kesederhanaan "kraton-kraton" itu, baik dalam penerapan teknologi tata-ruang maupun material yang digunakan. Keseluruhannya telah hancur dimakan waktu, selain -mungkin-telah digunakan kembali oleh generasi berikutnya untuk kepentingan yang berbeda

Di Bangkalan kita dapat menjumpai Kompleks Makam Sultan yang berada di bagian belakang kompleks Masjid Jamik Bangkalan, yang secara administratif masuk dalam wilayah Dusun Demangan. Kelurahan Demangan, Kecamatan Bangkalan. Adapun kraton dari masa pemerintahan Pangeran Adipati Cakraningrat V (sekitar tahun 1747) telah dihancurkan oleh Belanda dan lokasinya digunakan untuk membangun dalem, tempat tinggal bupati yang diangkat oleh Belanda. Di sebelah utara lokasi itu, masuk dalam wilayah Kelurahan Pejagan, pada tahun 1753 dibangum sebuah benteng Belanda yang sekarang difungsikan sebagai asrama polisi 
Satu hal yang cukup menonjol dari peninggalan budaya di Madura Barat, adalah besarnya pengaruh Jawa. Hal ini sejalan dengan kenyataan bahwa unsur penguasa di sana memiliki hubungan yang erat dengan Jawa, genealogis maupun politis. Kecenderungan untuk penerapan beberapa bagian dari pola budaya Jawa bagi mereka tentu dapat dikaitkan dengan upaya menjaga penampilan yang serasi dengan kekuasaan pusat di Jawa. Sedangkan pemanfaatan beberapa aspek budaya setempat tetap dilakukan karena bagaimanapun itu adalah sesuatu yang melingkungi kehidupannya sehari-hari Perpaduan dari keduanya terlihat menghasilkan sebuah keharmonisan, setidak-tidaknya dari segi seni-budaya. Kita juga dapat merasakan bahwa kondisi geografis Jawa dan Madura yang terpisah, oleh adanya Selat Madura, sebetulnya tidak mutlak memisahkannya karena unsur mobilitas antara penduduk kedua pulau tersebut sangat memadai dalam membentuk kesatuan sikap keruangan. Tampaknya kita sepakat juga untuk menerima ide bahwa unsur ruang sangat fundamental dalam pembentukan kehidupan bersama, sekaligus dalam pelaksanaan berbagai praktek kekuasaan.

Harus juga diingat bahwa aktivitas dalam bidang kemiliteran dapat juga dipandang sebagai unsur pendorong terjadinya kontak antara Madura dan daratan Jawa. Fakta mengenai ekspedisi yang melibatkan orang atau pasukan Madura (Barat), antara lain peristiwa pada masa Pangeran Cakraningrat IV untuk memadamkan pemberontakan orang Cina (Geger Pecinan) di Kartasura tahun 1741.

Dalam kaitannya dengan keberadaan pusat-pusat kekuasaan di Madura Barat, selain perdagangan laut dan pelayaran, kektlasaan politik cukup berperanan dalam proses pengintegrasian daerah-daerah di sekitar Selat Madura, khususnya, bandar-bandar pantai di pesisir Madura Barat. Selain hal tersebut di atas, walaupun tidak setua pelayaran dan perdagangan laut, faktor agama cukup berperan dalam proses pengintegrasiannya.

Berdasarkan sumber sejarah maupun peninggalan arkeologi, kita juga mengetahui bahwa daerah Sumenep (lazim disebut Madura Timur) telah másuk dalam kekuasaan Kompeni sejak tahun 1686, sedangkan Madura Barat baru mengalami hal itu pada tahun 1741 Beberapa saat setelah itu, dalam tahun 1745, kekuasaan Kompeni di seluruh Madura tampak mulai kuat (Hageman,1857)

Terlepas dari berbagai faktor di atas, bandar-bandar di Madura Barat -yang sebagian menjadi lokasi dari pusat institusi kekuasaanpada umumnya muncul di jaringan sistem transportasi, pada tempat pemberhentian alat transportasi, atau tempat untuk memindahkan barang yang diangkut seperti muara sungai dan lainnya Selat Madura 
sebagai bagian ruas jalur simpang dari jalur pokok pelayaran tradisional Nusantara yang membentang dari barat ke tımur, Ikut memberikan andilnya.

Melalur peninggalan budayanya pula kita dapat mengetahuı bahwa pelayaran memiliki peran yang besar dalam kehidupan keseharian masyarakat Madura, sehingga mudah dimengerti bila sebuah tempat yang baru muncul, yang tumbuhnya berkat adanya pelayaran, diberi nama sebuah bagian dari perahu. Bangkalan, juga sebuah pusat pemerintahan, yang dalam bahasa Madura memiliki arti anjungan atau bagian depan sebuah perahu, adalah salah satu contohnya.

\section{Kepustakaan}

Aziz, Abdul, 1927. Een kijkje in Madoera's verleden, dalam Djawa, Tahun ke-7, Nomor 3. hal. 153-163. Weltevreden: Java Instituut.

Darmosoetopo, R. (1980). Sedikit Uraian Tentang Pergantian Tahta (Kerajaan Indonesia Kuna Dari Abad 4 - 11 M). Berkala Arkeologi, 1(1), 52-57. https:II doi.org110.30883ljba.v1i1.276

Djafar, Hasan, 1978. Glrindrawarddhana, Beberapa Masalah Majapahit Akhir Jakarta Yayasan Dana Pendidikan Buddhis

Nalanda Graaf,HJ de,1940. De opkomst van Raden Troenadjaja dalam Djawa, Tahun ke-20. hal. 56-86 Weltevreden: Java Instituut.

Graaf,HJ de \& Th G Th Pigeaud,1974. De eerste Moslimse vorstendommen op Java, dalam VKI Deel 69. 's-Gravenhage: Martinus Nijhoff

Hageman, J, 1857. De Engelschen op Java, eerste perrode loopende tot 1623, dalam TBG VI

1857. Geschiedkundig overzigi van Madoera, dalam Madoera, MS KITLV; H14 
Hoorn, SC Keller Van, 1889. De Labang Mesem te Tandjoeng Anjar op hel eiland Madoera (Bangkalan), dalam TBG Deel 32. hal 431. 434. Batavia: Albrecht \& Rusche,

Kamar, Pa', 1926. Geschiedenis Van Madoera, dalam Djawa, Tahun Ke-6. hal. 231-250. Weltevreden: Java Instituut

Kartodirdjo, Sartono (ed.), 1973 Sejarah Perlawanan-Perlawanan Terhadap Kolonialisme. Jakarta: Pusat Sejarah ABRI

Kempers, AJ Bernet, 1959 Ancient Indonesian Art Amsterdam CPJ van Der Peet

Koestoro, Lucas Partanda, 1981. Peninjauan Kepurbakalaan Di Arosbaya dan Blega, Kabupaten Bangkalan, Jawa Timur. Yogyakarta: Balai Arkeologi Yogyakarta.

Koestoro, L. P. (1985), Catatan Singkat Mengenai Unsur Perkotaan Di Blega, Berkala Arkeologi, 6(1), 67-82, https://doi,org/10,30883ljba,v6i1,437

Padmapuspita, J, 1966. Pararaton, Teks Bahasa Kawi Terdjemahan Bahasa Indonesia Jogjakarta: Penerbit Taman Siswa

Slametmulyana, 1979. Nagarakretagama Dan Tafsir Sejarahnya Jakarta: Bhratara Karya Aksara

Stikke, DG et. al (ed.), 1927. Encyclopaedie Van Nederlandsch Indie (Vijfde Deel). s'Gravenhage: Martinus Nijhoff

Sutjipto, FA, 1978. Maciura dan Jawa Timur (Beberapa catatan tentang antar hubungan), dalam Buletin Fakultas Sastra dan Kebudayaan Nomor 6. hal. 117-124. Yogyakarta: Fakultas Sastra dan Kebudayaan UGM

(ed.), 1977. Sejarah Nasional Indonesia IV Jakarta Balai Pustaka 
Tjiptoatmodjo, FA Sutjipto, 1983. Kota-Kota Pantai Di Sekitar Selat Madure (Abad XVII Sempai Medio Abad XIX). Disertasi pada UGM Yogyakarta

Vorderman, AG, 1893. Over eenige weinig bekende oudheden van de residentie Madoera, dalam TITLV Deel 36. hal. 233-246. Batavia: Albrecht \& Rusche.

Wibowo, A. (1983). Nagarakertagama Dan Trowulan. Berkala Arkeologi, 4(1), 1-20. https://doi.org/10.30883/jba.v4i1.300 


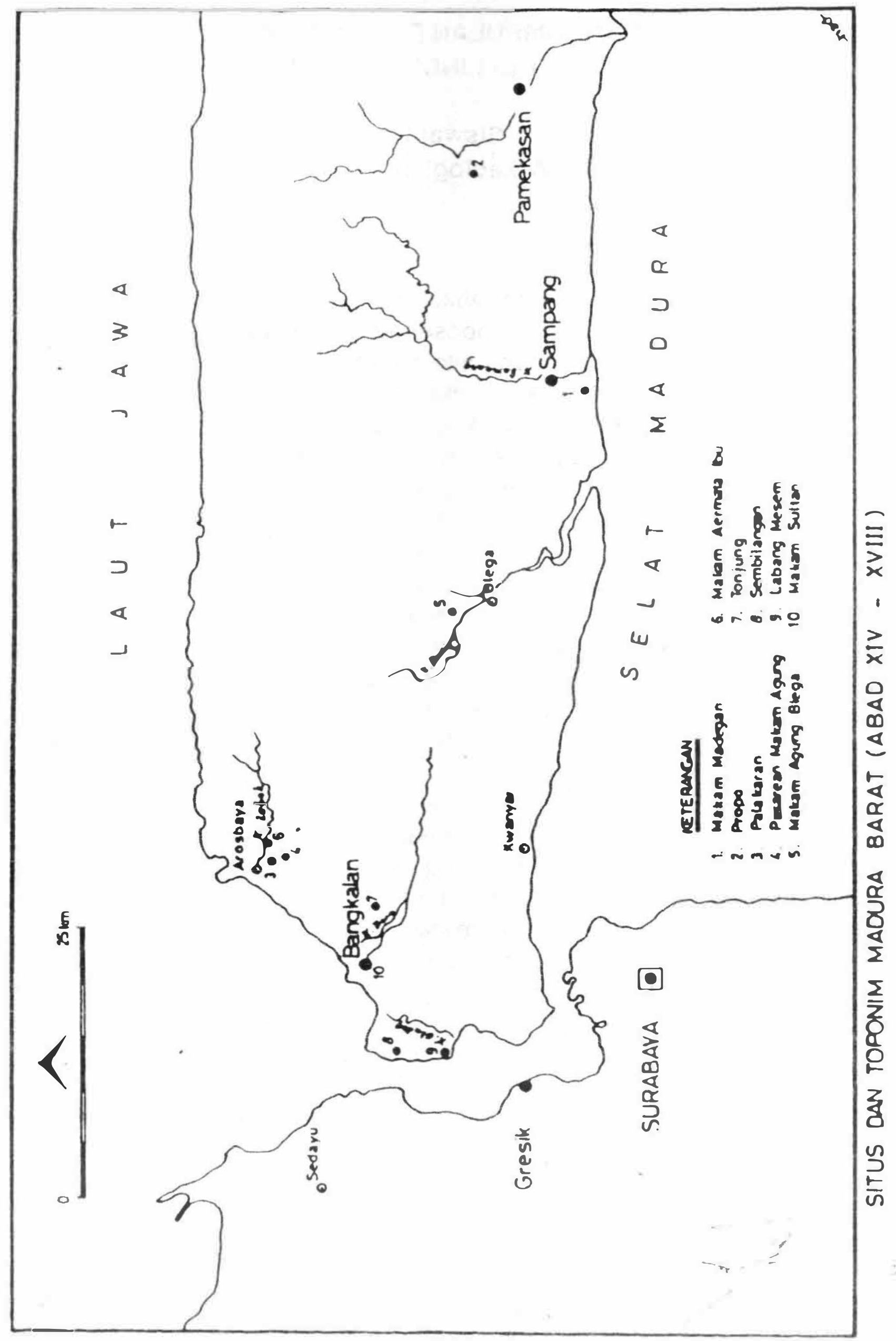

Berkala Arkeologi Th. XV - (2) - 